\title{
Li Zhensheng, Red-Color News Soldier
}

New York, Phaidon, 2003, 315 p.

Jean-Philippe Béja

\section{OpenEdition}

\section{Journals}

Édition électronique

URL : http://journals.openedition.org/chinaperspectives/469

DOI : $10.4000 /$ chinaperspectives.469

ISSN : 1996-4617

Éditeur

Centre d'étude français sur la Chine contemporaine

Édition imprimée

Date de publication : 1 avril 2005

ISSN : 2070-3449

\section{Référence électronique}

Jean-Philippe Béja, « Li Zhensheng, Red-Color News Soldier », China Perspectives [En ligne], 58 | march april 2005, mis en ligne le 29 novembre 2006, consulté le 21 septembre 2020. URL : http://

journals.openedition.org/chinaperspectives/469; DOI : https://doi.org/10.4000/chinaperspectives. 469

Ce document a été généré automatiquement le 21 septembre 2020

(c) All rights reserved 


\section{Li Zhensheng, Red-Color News Soldier}

New York, Phaidon, 2003, 315 p.

Jean-Philippe Béja

\section{NOTE DE L'ÉDITEUR}

Translated from the French original by Philip Liddell

1 The title of this work is apposite since for once, among recently published books on China, the cover reference to Mao is not unwarranted. Indeed, Li Zhensheng's photos take us back to the great moments of the "socialist transformation". Those familiar with the special issues of Paris Match on China will be surprised. No consumerism, no bold-eyed models-it is the "Cultural Revolution style" that illumines the pages of the book. The ten men in swimming trunks reading the Little Red Book before springing into the water on July 16th 1968, in celebration of the Great Helmsman's dip in the Yangtze two years before: perhaps one of them is today a businessman, a "Master of the Universe", like those depicted on the business pages of our newspapers (p. 220). We should not forget that these images are of a not-so-distant past, or that the young people photographed are today in their middle years.

2 Thus we are travelling in time. But the book's main point of interest is that, on the whole, these are official photographs for the photographer was no dissident. Far from it! Employed as a photojournalist for the Heilongjiang Daily, his job was to express in pictures for the official press the key points of Party policy. Li has preserved these photos through the years-having accumulated tens of thousands of negatives and sent them abroad-through all those changes in the Party Line, and the downfall of so many leaders ; and it is this continuity-we could say, this obstinacy-that gives the book its originality and the documents their value.

Indeed, present-day China is noteworthy for its refusal to look events squarely in the face : when a new leader rises to power, or when policy is changed, China rewrites its history while suppressing the photographs that sustain the old version. Li Zhensheng gives us the impression he is showing us round Party Committee archives in China's 
most northerly province, Heilongjiang. He was not shooting clandestinely when he photographed the "counter-revolutionaries", their necks bent under the weight of placards advertising their crimes, or the "class enemies" each with a huge dunce's cap proclaiming his identity. At that time, the Party was proud to parade the secretaries of the provincial committee as revisionist enemies who, with bowed heads, were making honourable amends in public view (pp. 164-165). Only the tender-hearted among the petty-bourgeoisie could be outraged by the humiliation inflicted upon Deng Guoxing and Yuan Fengxiang in the village where they were denounced as "rich peasants" ( $p$. 50). Those of a truly proletarian mind could only rejoice at such a spectacle. As for the demolition of the temples (p. 101), the authorities were delighted by it, for it showed that Chinese people were ready to abjure feudalism.

4 Naked violence appears in many photos. Particularly the violence of young people towards the middle-aged. But, at the time, Peking was the Mecca for world revolution, not for world tourism. So the detailed narrative sequence showing the ordeal of the seven counter-revolutionaries and "thugs" (one of them had conspired to kill his lover's husband, from the parade in town to the place of execution, will perhaps offend those of a sensitive disposition. But they were the daily bread of the People's Republic. Moreover, Mao's death did not bring an end to such practices, as is shown in the photos of Wang Shouxin's execution in the outskirts of Harbin in February 1980.

In this book, an official photographer is publishing the official documents that were required of him over a period of ten years. The Party, which is accustomed to airbrushing history into oblivion and recreating it periodically, is here confronted by the reality of what it practised, and the results are explosive. Li Zhensheng is a talented photographer, and his attention to composition and lighting raise this atrocious document of present-day China to the status of a work of art : one through which, amid such unrestrained fanaticism, we perceive the occasional gleam of real human feelings. 